\title{
BILINGUISMO E MULTILINGUISMO (POLONÊS/OUTRA LÍNGUA E OUTRA LÍNGUA/POLONÊS) EM TERMOS HISTÓRICOS - CONTEXTO E PERSPECTIVAS DE PESQUISA
}

\author{
Polish-Foreign (and Foreign-Polish) Bilingualism in the Historical Plan- \\ The State of Research and Research Perspectives
}

\author{
Rafał ZARĘBSKI \\ Uniwersytet Łódzki \\ Universidade de Łódź \\ rafal.zarebski@uni.lodz.pl \\ https://orcid.org/0000-0003-1918-2169
}

RESUMO: O objetivo deste artigo é analisar o bilinguismo histórico, apontar as fontes de pesquisa e indicar possíveis perspectivas para futuras pesquisas. Na Polônia, fala-se muito de bilinguismo contemporâneo, embora recentemente há uma tendência de descrever casos individuais ou comportamentos linguísticos de grupos com um direcionamento histórico. Ademais, os fenômenos descritos anteriormente sob uma outra perspectiva são agora analisados no contexto de comportamentos bilíngues. $\mathrm{O}$ surgimento dessa abordagem diferente que enfatiza o papel do bilinguismo na história da língua polonesa é resultado de vários fatores. O mais importante é o fato de que a abordagem normativa na qual os traços de contatos linguísticos eram avaliados de maneira negativa perdeu popularidade entre os pesquisadores. Além disso, o bilinguismo do passado não é mais tratado como um fenômeno marginal. PALAVRAS-CHAVE: Bilinguismo; História da língua polonesa; Contatos linguísticos.

\begin{abstract}
The aim of the paper is to analyze historical bilingualism, stress the sources for research and try to indicate possible perspectives for further research. The Polish researchers are interested mainly in contemporary bilingualism although recently one can observe a growing tendency to describe individual and group bilingualism from a historical plan. Moreover, the problems which were earlier treated from other perspective are now analyzed in the context of bilingual behaviour. This different approach stressing the role of bilingualism in the history of Polish language is the result of several factors. The most important is the fact that a normative approach to language contacts that negatively assesses blending of languages is no longer popular. The bilingualism in the Polish linguistic past is also no longer treated as the marginal phenomenon.
\end{abstract}


KEYWORDS: Bilingualism; The history of Polish language; Language contacts.

STRESZCZENIE: Celem artykułu jest analiza dwujęzyczności historycznej, wskazanie źródeł do jej badań oraz próba wyznaczenia możliwych perspektyw badawczych. Polskich badaczy interesuje przede wszystkim bilingwizm współczesny, choć ostatnio można zaobserwować rosnącą tendencję do opisywania dwujęzyczności indywidualnej i społecznej w planie historycznym. Ponadto niektóre zjawiska niegdyś opisywane z innej perspektywy obecnie analizuje się w kontekście zachowań dwujęzycznych. To odmienne podejście akcentujące rolę dwujęzyczności w historii języka polskiego jest wypadkową kilku czynników. Najważniejszy z nich wiąże się z odsunięciem na dalszy plan normatywnej koncepcji kontaktów językowych, w świetle której negatywnie oceniano fakt mieszania języków. Dwujęzyczność w polskiej przeszłości językowej nie może być zatem traktowana jako zjawisko marginalne. SŁOWA KLUCZOWE: Dwujęzyczność; Historia języka polskiego; Kontakty językowe.

\section{INTRODUÇÃO}

Embora os fenômenos do bilinguismo e do multilinguismo pareçam relativamente fáceis de se definir, há vários estudos linguísticos que propõem inúmeras e diferentes abordagens a respeito. Alguns concordam em delinear a essência da problemática, definindo, em geral, o bilinguismo como o uso de diferentes línguas, tanto quanto os determinantes desse fenômeno. Todavia, as características e aspectos mais importantes que o determinam se diferem significativamente. Minha intenção aqui, não é apresentar várias definições e compreensões do termo (LIPIŃSKA, 2003, p. 99-133), no entanto, gostaria apenas de sinalizar as diferenças básicas e alguns pontos controversos em relação à percepção do bilinguismo.

As diferenças significativas na compreensão do termo bilinguismo resultam do trecho presente na Enciclopédia de Linguística Geral/Encyklopedia językoznawstwa ogólnego (ELG): "uso de duas línguas diferentes no cotidiano por um determinado grupo social (...)" (POLAŃSKI, 1993) e em dois dicionários especializados franceses. No Grand Dictionnaire. Linguistique \& Science du langage (DUBOIS, 2007) o termo bilinguisme tem até sete significados, dos quais citarei o básico:

De um modo geral, o bilinguismo é um contexto linguístico no qual os sujeitos falantes são levados a usar alternadamente, dependendo do 
ambiente ou da situação que estão inseridos duas línguas diferentes Este é o caso mais comum de multilinguismo. ${ }^{1}(\mathrm{GD})$

No entanto, para as considerações feitas no decorrer deste trabalho, utilizaremos a definição proposta em Dictionnaire de didactique du français. Langue étrangère et seconde (CUQ, 2002):

Por bilinguismo, entendemos a coexistência, num indivíduo ou determinada comunidade, de duas variedades linguísticas: preferimos falar sobre 'variedades' porque, por um lado, o termo 'língua' é um conceito político em vez de linguístico (...) e, por outro lado, porque a mudança linguística ocorre cumulativamente no plano geográfico, social, funcional e diacrônico $(. . .)^{2}(\mathrm{DDF})^{3}$.

Esta última definição é tão ampla, que permite incluir, no escopo das questões discutidas, vários exemplos de coexistência de línguas, bem como suas variedades, tanto na produção individual quanto de grupo.

\section{OBJETIVO DESTA PESQUISA}

O termo bilinguismo está presente em pesquisas na Polônia, no campo da linguística aplicada, há várias décadas. No entanto, na área da linguística diacrônica apenas nos últimos anos parece se considerar parte dos comportamentos linguísticos históricos compreendidos por Stanisław Borawski (2000, p. 169) como uma legitimação textual da "história do uso do polonês, juntamente com todas as circunstâncias sociais, culturais, civilizatórias e políticas, indicando como consequências os contextos específicos ou

\footnotetext{
${ }^{1}$ No original: “D'une manière générale, le bilinguisme est la situation linguistique dans laquelle les sujets parlants sont conduits à utiliser alternativement, selon les milieux ou les situations, deux langues différentes. C'est le cas le plus courant du plurilinguisme".

Salvo indicação em contrário, as traduções das citações incluídas no texto são de autoria de Sônia E. Niewiadomski.

${ }^{2}$ No original: "On entend par bilinguisme la coexistence au sein d'une même personne ou société de deux variétés linguistiques : on préfère parler de " variétés » d'une part parce que « langue » est un concept politique plutôt que linguistique (...) et d'autre part parce que le changement linguistique s'opère de façon cumulative sur les plans géographique, social, fonctionnel et diachronique".

${ }^{3}$ Deixo de lado definições de outros conceitos intimamente relacionados ao bilinguismo: multilinguismo, plurilinguismo e diglossia (consulte DDF). Com base na literatura polonesa na área, esses termos foram amplamente referenciados por Ewa Lipińska (2003) em seu livro.
} 
destacando o percurso do processo histórico-linguístico"4, na perspectiva do bilinguismo ou multilinguismo.

O objetivo deste estudo é considerar o fenômeno sinalizado, isto é, o bilinguismo e o multilinguismo como uma questão amplamente ignorada no contexto da história da língua polonesa. Portanto, gostaria de apresentar brevemente um levantamento de pesquisas acerca de uma temática que é do meu interesse, referindo-me ao quadro recente e, finalmente, apresentar minhas próprias propostas de pesquisa, levando em consideração a literatura disponível. Meu interesse é principalmente o multilinguismo polonês/outra língua estrangeira como fenômeno diacrônico. Assim, uma análise dos vários fenômenos históricos relacionados ao bilinguismo e multilinguismo, os quais, infelizmente, possuem escassos exemplos sobreviventes até os nossos dias, põe em evidência essa problemática que é do nosso interesse em termos contemporâneos. É também um pano de fundo importante para os fenômenos contemporâneos, que, afinal, não são resultados dos tempos atuais, pois possuem um registro antigo e uma dimensão universal. Os estudos histórico-linguísticos podem explicar muitos desses fenômenos. Levar em conta interesses diacrônicos de várias manifestações de comportamentos linguísticos mais ou menos padrão, ${ }^{5}$ que documentam os fenômenos de coexistência do polonês e de outras línguas na fala de indivíduos pertencentes às comunidades de fala, bem como na fala dessas comunidades, talvez favoreça a adoção de uma ampla definição de bilinguismo e multilinguismo.

\section{LEVANTAMENTO DE PESQUISAS}

Quando escrevo acerca dos traços históricos dos comportamentos linguísticos, refiro-me às manifestações da coexistência do polonês com outras línguas pelos nossos antepassados na escrita e em registros sonoros, esses após a descoberta das possibilidades de gravação sonora da fala humana, como rádio, televisão e filme, bem como em forma digital. Trata-se aqui de uma literatura amplamente compreendida como escrita e, em relação ao século XX, também textos falados registrados em fita de áudio, em todas as variedades estilísticas e de gênero. Deve-se notar, no entanto, que certas áreas são

\footnotetext{
${ }^{4}$ No original: świadectwo "dziejów używania języka polskiego wraz z wszelkimi okolicznościami społecznymi, kulturowymi, cywilizacyjnymi i politycznymi, wskazującymi na przyczyny konkretnych stanów rzeczy lub naświetlającymi przebieg procesu historycznojęzykowego".

${ }^{5}$ Deve-se entender o adjetivo padrão como aquele de 'uso mais comum e que goza de aprovação social'.
} 
específicas para a pesquisa que nos interessa, principalmente a literatura de documentos pessoais, como correspondências, diários, memórias, recordações, mas também registros de conversas diárias, testemunho de estilo coloquial, textos não literários, além de documentos oficiais.

Os comportamentos linguísticos refletem o fenômeno do bilinguismo e, menos frequentemente, o multilinguismo, em certas etapas da história da língua polonesa, em condições sociais específicas, podendo assumir a forma de comportamentos modelo e posteriormente reproduzidos por membros da comunidade de fala polonesa (bilinguismo polonês/latim, polonês/francês). Nos estudos do bilinguismo do passado (polonês/outra língua e também de outra língua/polonês), vale a pena fazer referência à várias metodologias linguísticas: a sociolinguística tradicional; a concepção de Borawski baseada na análise da história do uso da língua por comunidades de fala, caracterizado por determinados comportamentos linguísticos; ou pela antropologia linguística na perspectiva de André Jacob e, na Polônia, no campo da linguística cultural por Janusz Anusiewicz, abordada por Bronisława Ligara (1987; 2010; 2011; 2011; 2014a; 2014b). Em pesquisas mundiais, as descrições diacrônicas do bilinguismo, principalmente com a presença do latim), são conhecidas há mais tempo e realizadas em larga escala (VIDOS, 1960; MOSS, 1994; HUCHON, 1995; KAPPLER; THIOLIER-MÉJEAN, 2009; LE BRIZ, VEYSSEYRE, 2010; AZEROUAL, 2016) ${ }^{6}$. Um olhar sob uma perspectiva bilíngue e multilíngue acerca da história da língua e reflexão sobre a língua enfatizam fortemente, entre outros, os estudiosos franceses: "O bilinguismo no século XVI, no entanto, não é apenas uma frivolidade do autor ou a ornamentação do editor. É a base de toda reflexão acerca da língua francesa"7 (HUCHON, 1995, p. 16).

O bilinguismo abordado sob uma perspectiva histórica é considerado uma subdisciplina da linguística diacrônica polonesa in statu nascendi $i^{8}$. Embora os casos, tanto os individuais quando os de grupos, de ocorrência da coexistência de línguas existam ao longo da história da língua polonesa, permaneceram à margem da pesquisa principal com um pressuposto de uma visão monolítica da língua como um meio de

\footnotetext{
${ }^{6}$ Há uma extensa literatura acerca do tema.

${ }^{7}$ No original: "Le bilinguisme au XVIème siècle toutefois n'est pas que coquetterie d'auteur ou ornementation d'éditeur. Il est au fondement de toute la réflexion sur le français"

${ }^{8}$ Bronisława Ligara (2018) é a precursora dessas pesquisas e defensora da ideia de que a crença acerca da natureza monolítica da língua polonesa do passado foi causada pela falta de interesse dos pesquisadores pelos comportamentos bilíngues.
} 
comunicação no território, historicamente em mudança, do Estado polonês. Ou também foram tratados apenas em termos de contatos linguísticos amplamente compreendidos, sem reconhecimento detalhado de sua natureza e, acima de tudo, sem uma reflexão mais profunda acerca dos produtos linguísticos desses contatos. Por outro lado, por exemplo, quando houve um interesse pelo idioleto de indivíduos bilíngues, foi abordado de uma perspectiva normativa, de um modo geral, avaliando negativamente a presença de elementos "estranhos", sem um contexto mais amplo e fatores que geralmente determinam esse comportamento linguístico (LIGARA, 2010, p. 142-143).

O campo de pesquisas acerca do bilinguismo e multilinguismo na história da língua polonesa é considerável. Os pesquisadores da época provavelmente não se davam conta disso, muitas vezes fortemente orientados para mostrar o antigo papel central da homogeneidade linguística. Embora tenham surgido estudos abordando o fenômeno dos contatos linguísticos, fazendo referência às ferramentas, incluindo terminologia, do campo do bilinguismo (BACKVIS, 1958; RZEPKA; WALCZAK, 1992), foram mais frequentes as pesquisas, cujos autores trataram esses contatos em termos de influência negativa na língua polonesa (KLEMENSIEWICZ, 1985) ou apenas como fonte de empréstimos léxicoestruturais (BUKOWCOWA; KUCAŁA, 1981; BUKOWCOWA, 2003, p. 137-161) sem se referir à análise dos mecanismos presentes na fala bilíngue. Os pesquisadores de novas abordagens diacrônicas consideram a necessidade de novas descrições ou reinterpretações de fatos no campo dessa problemática (por exemplo sobre bilinguismo polonês/francês: LIGARA, 1987; 2010; 2011; 2014a; 2014b; SZCZEPANKOWSKA, 2004, p. 173-201; polonês/latim: RZEPKA-WALCZAK, 1992; DUBISZ, 2002, p. 222-229; KUŹMICKI, 2013; KRĄŻYŃSKA; MIKA; SŁOBODA, 2015, p. 57-61; ZIÓŁKOWSKA, 2016, p. 28-29; MASŁEJ, 2018; polonês/tcheco: BOROWIEC, 2015).

\section{POSTULAÇÕES E PERSPECTIVAS DE PESQUISAS}

Bronisława Ligara apresenta uma proposta interessante em relação ao estudo do bilinguismo em termos diacrônicos. A pesquisadora postula que o bilinguismo de "notáveis usuários da língua polonesa" deve se tornar um campo de pesquisa distinto no contexto de estudos histórico-linguísticos. Segundo Ligara, na área de interesse dessa subdisciplina deve-se incluir fenômenos como: bilinguismo polonês/latim e latim/ polonês até o início do século XVIII; o bilinguismo polonês/francês de artistas do círculo 
da Grande Emigração9 ${ }^{9}$ o bilinguismo polonês/outra língua (polonês/alemão, polonês/ francês, polonês/lituano, etc.) nas produções de autores posteriores, a partir do final do século XIX; o multilinguismo de autores como Joseph Conrad Korzeniowski ou Bronisław Malinowski; as obras bilingues de escritores que emigraram da Polônia durante a Segunda Guerra Mundial e no período pós-guerra (Witold Gombrowicz, Czesław Miłosz, Konstanty Jeleński, Gustaw Herling-Grudziński, Leopold Tyrmand e outros) (LIGARA, 2018, p. 101-102). Segundo a pesquisadora, uma característica completa da fala bilíngue de indivíduos notáveis na história da língua polonesa incluiria três planos: 1) formal (os modos de incluir os marcadores de transcodificação nos textos lineares heterogênicos); 2) funcional; 3) genológico (LIGARA, 2014b, p. 140-167; 2018, p. 105).

A concepção mencionada é totalmente aceitável, mesmo que apenas por esse motivo básico, que sua realização preencheria uma lacuna importante nos estudos históricolinguísticos da Polônia. Sabe-se que indivíduos notáveis, que se realizam no campo da escrita literária, podem influenciar significativamente no comportamento linguístico de um determinado grupo de representantes de uma dada comunidade linguística. No entanto, devemos lembrar que esses autores, os usuários mais sensíveis da língua, são apenas uma pequena parte de toda a comunidade de falantes. E por isso acredito que a presente proposta requer algumas complementações, que, consequentemente, poderiam criar uma área mais ampla desse campo de pesquisa, tornando-a autônoma em um futuro próximo, incluindo a descrição do bilinguismo em termos diacrônicos.

Primeiramente, com toda a riqueza estilístico-genológica da língua polonesa é possível reconhecer a variedade coloquial como "o centro do sistema de estilo da língua" e como "a base derivativa para demais estilos linguísticos" (BARTMIŃSKI, 2001, p. 116117) e percebê-la, também, como "pouco sensível a influências inovadoras, resultantes de necessidades individuais específicas" (BORAWSKI, 2000, p. 174). Então, um historiador da língua, focado na descrição dos comportamentos bilíngues, deve ampliar o campo de suas observações no que diz respeito a textos de indivíduos menos notáveis, simples e comuns. São os testemunhos deles que, como expressão de certos mecanismos gerais, mostram a automatização dos hábitos linguísticos e a disseminação dos comportamentos linguísticos. É suficiente dizer que, na perspectiva moderna, prevalecem as pesquisas sobre o bilinguismo e o multilinguismo em pessoas comuns (por exemplo, MIODUNKA,

\footnotetext{
${ }^{9}$ Grande Emigração é um movimento de saída da população polonesa, com origem política, decorrente da derrota do Levante de Novembro no ano 1831. Entre os emigrantes encontravam-se vários escritores, artistas e intelectuais poloneses, tais como: Adam Mickiewicz, Juliusz Słowacki, Fryderyk Chopin, entre outros (Nota da redação).
} 
2003). Situação que naturalmente pode ser resultado das diferentes especificidades dos objetos de pesquisa e da maior acessibilidade às fontes adequadas, que são escassas em relação aos tempos passados.

Assim, cientes do papel do estilo coloquial e do papel do falante comum da língua, os autores de uma das antologias de textos da história da língua polonesa mencionam na introdução:

\begin{abstract}
A mais uniforme é a variedade coloquial. Essa língua, a língua de milhões de poloneses que constituem a comunidade de fala nacional e que desenvolvem a cultura nacional, é a base da língua literária. Isso não significa que no desenvolvimento da nossa cultura social não damos importância aos indivíduos notáveis, cuja língua é, no geral, modelo. Valorizamos, mas ao mesmo tempo, queremos fornecer ao leitor material para distinguir o que é padrão nos comportamentos linguísticos e o que é modelo. Confundir ambas categorias conceituais acaba resultando na criação de falsas imagens do passado linguístico - o endeusamento de certos períodos, processos, pessoas e a desvalorização de outros ${ }^{10}$ (BORAWSKI; FURDAL, 2003, p. 15).
\end{abstract}

Um exemplo de estudo que vai ao encontro do postulado aqui proposto de incluir, no âmbito de pesquisas acerca da fala bilíngue, os usuários e/ou falantes menos notáveis no campo da produção literária, é a descrição do bilinguismo polonês/francês de três autoras dos séculos XVIII e XIX, pertencentes à camada aristocrática magnata, feita por Irena Szczepankowska (2004, p. 173-201). Nesse contexto, as aristocratas Teofila Sapieżyna, Franciszka Urszula Radziwiłłowa e Kamila Bystrzonowska falavam tanto a língua polonesa quanto a francesa. Desde tenra idade assimilando o francês, representando assim o bilinguismo coordenado, este não estava livre de certos equívocos e negligências, especialmente no polonês. Uma outra variedade semelhante de bilinguismo podemos verificar nas correspondências do rei Jan III Sobieski ${ }^{11}$ com sua esposa, Maria Casimire Louise de La Grange d'Arquien (ZARĘBSKI, 2019). Numa análise superficial das cartas

${ }^{10}$ No original: "Najbardziej jednolita jest odmiana potoczna. Ona właśnie, język milionów Polaków tworzących narodową wspólnotę komunikatywną i swoją działalnością rozwijających narodową kulturę, jest podstawą języka literackiego. Nie znaczy to, byśmy w rozwoju naszej kultury społecznej nie doceniali znaczenia jednostek wybitnych, których język ma dla ogółu wartość wzorcową. Doceniamy, ale zarazem pragniemy dostarczyć czytelnikowi materiału do odróżnienia tego co w językowych zachowaniach wzorcowe, od tego co typowe. Mylenie obydwu kategorii pojęciowych skutkuje powstawaniem fałszywych obrazów językowej przeszłości idealizowaniem pewnych okresów, procesów i osób, a pomniejszaniem innych".

${ }^{11}$ Rei da Polônia nos anos 1674 - 1696 (Nota da redação). 
do governante podemos observar várias formas de contatos linguísticos (switching code, code mixing e interferências nos níveis lexical e gramatical) (HAMERS; BLANC, 1983, p. 194-205; LIGARA, 2010 e 2014b), como os seguintes:

- switching code: “Owo widzę, że mię twoje wdzięczne tak oczarowały oczy, że bez nich i momentu wytrwać będzie niepodobna, i tak tuszę, że notre amour ne changera jamais en amitié, ni en la plus tender qui fût jamais" ("Vejo que seus olhos graciosos me encantaram, que sem eles e o momento será impossível suportar, mesmo assim eu anseio, que notre amour...");

- mixing code: "Niesłychaną mamy incommodité [falta de artigo em françês, quebrando a regra gramatical da L2] w tej drodze, co niczego na świecie nie dostanie", ("Temos uma incommodité inusitada nesse caminho, a qual nada no mundo alcançará")

- interferências ${ }^{13}$ como, por exemplo, broderować - de francês broder (bordar), franchiza - de francês franchise (franqueza).

Assim, pode-se considerar os textos estudados, relacionados com correspondência e diários, como um produto, até certo ponto, característico de comportamentos linguísticos. Naturalmente, precisamos lembrar que o bilinguismo polonês/francês não contemplou toda a comunidade de fala polonesa, mas apenas uma parte dela - algumas camadas dentro da comunidade aristocrática magnata e, depois, mais ou menos até a eclosão da Segunda Guerra Mundial, os proprietários de terras e a elite intelectual.

O maior problema, pelo menos ao que parece, nos estudos histórico-linguísticos, principalmente nas pesquisas acerca do bilinguismo e multilinguismo, é a escassez de base material suficiente. As lacunas nessa área, às vezes, despertam certas generalizações nem sempre verdadeiras. Há menos documentos que registram a escrita de falantes e usuários comuns da língua, consequentemente, há menos traços de seu bilinguismo. Isso leva à conclusão de que o bilinguismo foi especialmente significativo para algumas camadas mais altas, e mesmo assim sabemos que esse fenômeno ocorreu em indivíduos ou grupos comuns.

Em segundo lugar, é importante também complementar o conceito de Ligara em relação ao postulado acerca das pesquisas do bilinguismo e multilinguismo de indivíduos e grupos maiores que tinham o polonês como segunda língua. Os historiadores da língua interessaram-se principalmente por esse tipo de bilinguismo, que é descrito

\footnotetext{
${ }^{12}$ Os trechos em negrito referem-se a palavras em francês, sendo que as partes sem destaque são em polonês (Nota da redação).
}

${ }^{13}$ Por conta da amplitude do problema, refiro-me somente a interferências na forma de empréstimos lexicais. Para saber mais sobre o tema, consulte LIGARA, 2010, p. 154-166. 
como subordinado ao polonês como primeira língua. O bilinguismo coordenado, isto é, uso e domínio de ambos os códigos ao mesmo tempo, desde tenra idade, podemos ver, por exemplo, em relação à alguns representantes da antiga aristocracia que aprenderam francês desde a infância (LIGARA, 2015). A análise da fala de indivíduos bilíngues, que representam o bilinguismo do passado outra língua/polonês, é um campo ainda completamente desconhecido. Deve-se dizer de imediato que não há muitos registros desse gênero e, quando há, eles são com certeza altamente dispersos.

Neste ponto, gostaria de chamar a atenção para dois casos em termos de bilinguismo francês/polonês de duas figuras do século XVII: Maria Casimire Louise de La Grange d'Arquien, conhecida como rainha Marysieńka ${ }^{14}$ e François-Paulina Dalairaca ${ }^{15}$. A rainha Marysieńka, nascida na França, com quatro anos de idade foi à Polônia com Maria Luísa Gonzaga e, depois, retornou à França, onde estudou na escola de convento das ursulinas, mais tarde voltou à Varsóvia, em 1652 ou 1653 (KUKULSKI, 1966a, p. 10). Conversava com as damas da corte em francês, enquanto em suas cartas aos seus maridos (Jan Zamoyski e depois Jan Sobieski) mesclava francês com polonês (é claro que as cartas eram escritas em francês, mas há presença da língua polonesa - de palavras simples a segmentos mais longos). Urbańczyk (1967, p. 169) afirmou que "era fluente em polonês e conhecia várias sutilezas" ${ }^{16}$.

No entanto, não é tão simples determinar os fatos da biografia linguística de F. Dalairaca, porque sabemos pouco sobre sua vida devido à falta de documentos. Nasceu na França, onde viveu como súdito de Luís XIV, foi conselheiro do rei Jan III Sobieski e sua esposa Marysieńka, mensageiro de cartas da realeza de Viena e Parkan ${ }^{17}$, prisioneiro em cativeiro turco e membro de várias missões diplomáticas (FOLKIERSKI, 1925). O enredo desse precioso diário (D I-II), em termos históricos, abrange o período da guerra entre os poloneses e os otomanos, na segunda metade do século XVII, em especial os acontecimentos de 1683.

Para ilustrar a complexidade da problemática do funcionamento de diferentes línguas no mesmo texto, rememoramos curtos fragmentos do legado de ambos os autores:

\footnotetext{
${ }^{14}$ Marysieńka é a forma diminutiva de Maria (Nota da redação).

${ }^{15}$ Outras versões do sobrenome: Dalerac, Dallerac, d'Allayrac ou na versão "polonizada": Franciszek Paulin Dalerak (FOLKIERSKI, 1925, p. 5).

${ }^{16}$ No original: "Władała polszczyzną biegle i znała różne jej subtelności”.

${ }^{17}$ Trata-se de lugares de batalhas da Grande Guerra Turca (1683-1699), durante a qual Jan III Sobieski liderou o exército polonês-austro-alemão (Santa Liga). (Nota da redação)
} 
(...) en sorte qu'une maison de maçonnerie, pierre ou brique, a un nom particulier pour la distinguer du mot general de maison, lequel convient à toutes, soit de bois, soit d'autre matiere; ce nom particulier est kaminitsa, qu'ils expliquent en latin par celuy de lapidea, au lieu que le terme generique, est domo, ou gospodi ${ }^{18}$ (DALAIRAC, 1699, p. 261).

(Assim uma casa de alvenaria, pedra ou tijolo, tem um nome específico para distingui-la da palavra casa, em um sentido geral, adequada para todos os tipos, seja de madeira ou de outro material; esse nome em particular é kamienica, em latim traduzida como lapidea, em vez do termo genérico da terminação geral dom (casa) ou gospoda)

Il me paraît, sze nie ma Baulieu wątpicz, bo uznala, sze ta osoba dosycz nie obludna; niech tego będzie pewna, a niech o kim nie spiskuie, parce que les autres sont jugés par nous-mêmes, a sze tu nietrudno o inszych, wszitko to znaczi, co sami radzi cziniemy, to o inszych rozumiemy (KUKULSKI, 1966b, p. 185) ${ }^{19}$.

(Il me paraît, que não tem Baulieu dúvidas, pois decidiu, que essa pessoa não é tão hipócrita; que tenha certeza disso e que não conspire contra alguém, parce que les autres sont jugés par nous-mêmes, e já que outros não faltam, tudo isso significa que fazemos contentes o que entendemos dos outros)

"un chłop gruby" (um camponês gordo - KUKULSKI, 1966b, p. 161), "un nieszczery syn" (um filho não sincero - KUKULSKI, 1966b, p. 145), "avec une grande ochota" (com uma grande vontade - KUKULSKI, 1966b, p. 145).

Há descrições em andamento do bilinguismo e do multilinguismo dos mais antigos textos poloneses (KUŹMICKI, 2013; KRĄŻYŃSKA; MIKA; SŁOBODA, 2015, p. 57-61; ZIÓŁKOWSKA, 2016, p. 28-29; MASŁEJ, 2018). De uma perspectiva semelhante, mas não idêntica, devido à expansão e prestígio da língua polonesa nos séculos subsequentes, deve-se olhar para as produções renascentistas polonesas-latinas e textos posteriores fortemente marcados pela presença do latim, tratados, até o presente momento, como interferências ${ }^{20}$.

\footnotetext{
${ }^{18}$ As citações francesas estão em sua grafia original.

${ }^{19}$ Fragmento em polonês com grafia diferenciada a qual indica as influências no nível fonético da língua francesa (Nota da redação).
}

20 Nota da tradutora: $\mathrm{O}$ autor do texto utiliza a palavra makaronizowane - um termo pejorativo para a introdução de palavras, expressões ou terminações estrangeiras, no caso aqui latinas, na fala ou escrita (uma mescla de polonês com latim, com o latim influenciando fortemente a estrutura das sentenças polonesas e a ordem das palavras) - por isso optamos utilizar o termo interferência. 
Destacar o papel do bilinguismo e do multilinguismo nos estudos diacrônicos permite incluir o interesse nesse campo a literatura amplamente compreendida como escrita, traços individuais como também de grupo, da área de contatos do polonês com outras línguas, além do latim e francês, que eram, do mesmo modo, fortes e constantes, e às vezes até mais presentes na vida de nossos antepassados linguísticos (alemão, russo, ídiche, línguas rutenas etc.). Para tanto, vale a pena acrescentar mais uma pequena e importante observação. Precisamos lembrar que as abordagens mais recentes ampliam a compreensão do bilinguismo e incluem os contatos das variedades (dialetos, línguas regionais etc., ver variété no DDF) que não possuem status de língua ou cujo status está em discussão ${ }^{21}$. Assim, englobar múltiplos contatos do polonês em termos de estudos multilíngues específicos amplia e enriquece significativamente a história tradicional da língua (WALCZAK, 2014, p. 186).

Imprescindivelmente a fala documentada é um tipo fundamental de fonte de pesquisas, mas não o único, acerca do bilinguismo e multilinguismo em aspectos históricos básicos. Há uma gama de textos disponíveis acerca da história da língua polonesa (WYDRA; RZEPKA, 1995; TASZYCKI, 1969). No entanto, registros documentando o bilinguismo do passado existem poucos. Principalmente são textos em polonês/latim dos séculos XII até XVIII e esporadicamente com a presença de outras línguas, por exemplo, texto em polonês/ruteno com escrita cirílica de 1630 (TASZYCKI, 1969).

Nos textos selecionados por Cybulski (2015b, p. 59-61) foi inserido um fragmento interessante em polonês/francês, do século XIX, de uma conversa citada no editorial de Marcel Motty de 1865:
“Jakże się pani bawiłaś na składkowych wieczorkach?”- „Co do mnie, siedziałam avec les mamans; rozmawiałyśmy o bliźnich, a w końcu, to było bardzo późno, ziewałam i oczy mi się kleiły; ale się pan spytaj Maryni” - „O c'était charmant, rzecze panna Marynia - on a dansé aż do rana, bawiłam się wybornie, aż dziesięciu minut nie siedziałam, i pan Wiktor téż był."
("Como passou o tempo no encontro beneficente?" - "Eu fiquei avec les mamans, conversávamos sobre os próximos, e no final já estava tarde, bocejava e estava com sono, mas pergunte a Marynia." - "O c'était charmant, disse senhorita Marynia - o a dansé até o amanhecer, diverti- me muito, não fiquei sentada nem por dez minutos e senhor Wiktor também esteve lá")

Além disso, as antologias mais recentes (BORAWSKI; FURDAL 2003;

\footnotetext{
${ }^{21}$ Estamos ignorando considerações detalhadas acerca desse tema.
} 
CYBULSKI, 2015a; 2015b) contêm alguns trechos da Polônia étnica, em que podemos observar fenômenos relacionados à diglossia (polonês/cassúbio e polonês/silesiano). De um modo geral, uma consulta aos recursos de antologias mais antigas e mais recentes de textos acerca da história da língua evidenciou que o fenômeno do bilinguismo, que não seja o polonês/latim, está muito mal representado. Como pode-se imaginar, o conteúdo dessas antologias foi influenciado, conforme já sinalizado no decorrer do texto, em uma concepção não totalmente verdadeira: a concepção monolítica da comunidade de fala polonesa em termos linguísticos.

\section{FONTES DE PESQUISA}

Portanto, a tarefa dos pesquisadores contemporâneos é, num primeiro momento, trazer à luz e analisar (incluindo a descrição de fenômenos de nosso interesse em textos já conhecidos, por exemplo, cartas de Chopin ou Słowacki) outros antigos registros de bilinguismo com a presença do polonês. Devemos também dar uma atenção especial aos arquivos mais antigos e mais recentes fora da Polônia. Aqui, podemos mencionar pesquisas sobre o bilinguismo polonês/português no Brasil realizadas, entre outros, outrora por Władysław T. Miodunka (2003) e atualmente, em termos diacrônicos, por Izabela Stąpor (2016). Além dos textos já citados, de um passado linguístico mais distante, que documentam o bilinguismo de indivíduos com consciência linguística média, bem como aqueles que adquiriram o polonês como segunda língua, também se faz necessário lembrar de outras possibilidades. No que diz respeito ao estudo do bilinguismo e do multilinguismo em termos diacrônicos, podemos basear-se apenas nos registros dos traços preservados até hoje, mas não só. Ao longo do tempo, estudos acerca do bilinguismo, de forma mais vasta, poderão fazer uso de fontes registradas por meio de outros códigos que não sejam apenas os escritos, por exemplo, rádio, televisão. Hoje em dia, para esta finalidade, por exemplo, vale a pena buscar registros de fala bilíngue disponibilizadas nos bancos de dados online. Refiro-me aqui pelo menos ao portal "Arquivo da história oral" (http:// www.audiohistoria.pl/web/) e, em particular, gravações específicas da série "Poloneses na França" (https://audiohistoria.pl/zbiory/55-ahm_3190?page=2) ou "Varsóvia multiétnica. Estrangeiros moradores da capital 1945-1989" (https://audiohistoria.pl/zbiory/28warszawa-wielonarodowcówcudzoziemscy-mieszkancy-sto). Outra fonte valiosa que já pode ser considerada histórica é, por exemplo, o arquivo a Kultura paryska ${ }^{22}$,

${ }^{22}$ Kultura era um periódico de emigração polonesa publicado nos anos 1947-2000, primeiramente em Roma (Itália) e, a partir do ano 1948, em Paris (França) (Nota da redação). 
parcialmente disponível em formato digital. Em seus recursos preservaram-se cartas pessoais, anotações, curtas notas confirmando a fala bilíngue de vários personagens ao redor de Jerzy Giedroyćc ${ }^{23}$.

\section{CONCLUSÃO}

Concluindo, gostaria de chamar a atenção para algumas considerações mais importantes que podemos extrair das observações acerca do bilinguismo e multilinguismo nas pesquisas diacrônicas polonesas.

Primeiramente, a temática, embora discutida, na literatura histórico-linguística da Polônia está pouco presente. Este estado ressalta fortemente a crença de natureza monolítica, em termos linguísticos, da comunidade de fala polonesa no passado, ou melhor das comunidades de fala. Em várias etapas da história do uso da língua polonesa, dependendo de inúmeros fatores externos complexos (políticos, sociais e demográficos), o polonês permaneceu em contato com outros idiomas. A mudança da óptica outrora normativa na descrição da coexistência do polonês com outras línguas para uma abordagem socioantropológica, postulada por Ligara, pode resultar em novas interpretações a respeito dos comportamentos linguísticos do passado.

Em segundo lugar, é preciso ter em mente a especificidade das fontes que evidenciam o bilínguismo e multilinguismo do passado. Antes de tudo, pertencem à elas textos em que observamos, não apenas, "uso de duas ou mais línguas diferentes sequencialmente ou alternadamente (...), com clara intencionalidade literária" ${ }^{24}$, mas acima de tudo aqueles em que “(...) a mescla de línguas assume uma função decisiva do instrumento de expressão de uma realidade social e cultural" 25 (CUNHA, 2009, p. 79). A história da língua como uma ciência, que tem como objeto apenas os fatos disponíveis atualmente, não é tanto uma reconstrução, mas apenas uma construção da visão linguística do passado. Portanto, são significativas as proporções entre o que o pesquisador contemporâneo dispõe e a imagem, sempre hipotética, das relações linguísticas de outrora. Com base na análise de inúmeras fontes polonesas/latinas, primeiramente medievais e depois do polonês médio,

\footnotetext{
${ }^{23} \mathrm{O}$ artigo de Anna Jamrozek-Sowa presente neste Dossiê trata, entre outros assuntos, da pessoa de Jerzy Giedroyć e sua atuação no periódico Kultura.

${ }^{24}$ No original: “(...) l'utilisation de deux ou de plusieurs langues différentes successivement ou en alternance (...), avec une claire intentionnalité littéraire",

${ }^{25}$ No original: “,(...) le mélange linguistique assume une fonction décisive d'instrument expressif d'une réalité sociale et culturelle“.
} 
não podemos formar uma opinião acerca do caráter bilíngue de toda a comunidade polonesa do passado. No entanto, podemos falar de alguns grupos bilíngues dentro dessa comunidade. A situação é semelhante em relação a outros tipos de bilinguismo ou, menos frequente, multilinguismo.

Terceira observação: assim como se fazem necessários estudos acerca do bilinguismo social e de grupos historicamente legitimados (inclusive no exterior) também são importantes as descrições de fala bilíngue de certos indivíduos. Comportamentos linguísticos individuais podem influenciar na configuração de certos padrões. Nessa questão gostaria de enfatizar o seguinte: um pesquisador da variedade linguística do passado deve se interessar não apenas pelo bilinguismo de indivíduos notáveis, com talento para escrita e com um considerável conhecimento linguístico, mas também por testemunhos linguísticos de pessoas com uma consciência linguística menor. Aqui, diante do historiador da língua, um explorador e buscador de material antigo, abre-se uma área muito pouco conhecida, cujo lugar central deve ser ocupado por documentos depositados na parte inferior dos arquivos, especialmente no campo da literatura amplamente compreendida como escrita privada, que graças às conquistas da tecnologia moderna se tornam mais acessíveis.

Finalmente, deve-se prestar atenção nos textos de indivíduos, cuja a segunda língua era o polonês. Essa questão é realmente completamente desconhecida nos estudos diacrônicos e, mais especificamente, no campo da sociolinguística histórica da língua polonesa. Pode-se argumentar que a descrição dos mecanismos bilíngues presentes nos testemunhos linguísticos outra língua/polonês (polonês como L2) de tais indivíduos comparados com os tipos de marcadores de transcodificação (LIGARA, 2014b, p. 156) em fontes polonesas/estrangeiras, poderiam ser úteis na identificação de alguns fenômenos e padrões gerais.

Tradução: Sônia Eliane Niewiadomski 


\section{REFERÊNCIAS:}

AZEROUAL, S.A. Bilinguisme et plurilinguisme dans l'éducation anglaise au XVI ${ }^{\mathrm{e}}$ siècle. Hypothèses, 2016/1, n. 19, p. 309-320. Disponível em: <https:/www.cairn.info/revuehypotheses-2016-1-page-309.htm>. Acesso em 05.06.2020.

BACKVIS, C. Quelques remarques sur le bilinguisme latino-polonais dans la Pologne du seizieme siecle, Bruxelles, 1958. (tradução para polonês Uwagi o dwujęzyczności tacińsko-polskiej w XVI wieku w Polsce In: BACKVIS, C. Szkice o kulturze staropolskiej, tradução de U. Dąmbska-Prokop, Warszawa: Państwowy Instytut Wydawniczy, 1975. p. 588-624).

BARTMIŃSKI, J. Styl potoczny. In: BARTMIŃSKI, J. (Org.). Współczesny język polski. Lublin: Wydawnictwo UMCS, 2001. p. 115-134.

BORAWSKI, S. Wprowadzenie do historii języka polskiego. Warszawa: PWN, 2000.

BORAWSKI, S.; FURDAL, A. Wybór tekstów do historii języka polskiego, Warszawa: PWN, 2003.

BOROWIEC, K. Dwujęzyczność pisarza i tekstu na średniowiecznym Śląsku. Rekonesans. In: MIKA, T.; ROJSZCZAK-ROBIŃSKA, D.; STRAMCZEWSKA, O (Orgs.). Staropolskie Spotkania językoznawcze, t. 1. Jak badać teksty staropolskie. Poznań: Wydawnictwo Rys, 2015. p. 19-38.

BUKOWCOWA, Z. (Org.) Bibliografia podręczna gramatyki historycznej $i$ historii języka polskiego. cz. IV. 1979-1993. Kraków: Wydawnictwo Lexis, 2003.

BUKOWCOWA, Z.; KUCAŁA, M.(Orgs.) Bibliografia podręczna gramatyki historycznej $i$ historii języka polskiego, cz. II. Stownictwo. Kontakty językowe. Wrocław-WarszawaKraków-Gdańsk-Łódź: Zakład Narodowy imienia Ossolińskich; Wydawnictwo PAN, 1981.

CUNHA, V. Le plurilinguisme comme le procédé stylistique dans la poésie médiévale galicienne portugaise. In: Le plurilinguisme au Moyen Âge. Paris : L'Harmattan, 2009. p. 79-93.

CUQ, J.P. DDF : Dictionnaire de didactique du français langue étrangère et seconde. Paris: CLE International, 2002.

CYBULSKI, M. Wybór tekstów z dziejów języka polskiego. Do połowy XIX w.. Łódź: Wydawnictwo UŁ, 2015a. 
CYBULSKI, M. Wybór tekstów z dziejów języka polskiego. Od połowy XIX w.. Łódź: Wydawnictwo UŁ, 2015 b.

DALAIRAC, F.-P. Les anecdotes de Pologne ou memoires secrets du regne de Jeans Sobieski III du nom. t. 1-2. Amsterdam: Henry Desbordes, 1699.

DUBISZ, S. Język - historia - kultura (wyktady, studia, analizy). Warszawa : Wydział Polonistyki Uniwersytetu Warszawskiego, 2002.

DUBOIS, J. et al. GD: Grand dictionnaire. Linguistique \& sciences du langage. Paris: Larousse, 2007.

FOLKIERSKI, W. Kłopoty francuskiego autora XVII wieku z polszczyzna. Kraków: Drukarnia W. L. Anczyca i Spółki, 1925.

HAMERS, J. F.; BLANC, M. Bilingualité et bilinguisme. Bruxelles: Pierre Mardaga, 1983.

HUCHON, M. Le plurilinguisme au XVIème siècle: Jeux et enjeux. Albineana, Cahiers d'Aubigné, 6. Agrippa d'Aubigné et le plurilinguisme. Journées d'études des 29-30 mai 1992, Poitiers. Musée Sainte-Croix, 1995, p. 15-27. Disponível em: $<$ https://www.persee. fr/doc/albin_1154-5852_1995_num_6_1_1334>. Acesso em 01.06.2020.

KAPPLER, C. ; THIOLIER-MEJEAN, S. (Orgs.) Le plurilinguisme au Moyen Âge. Paris: L'Harmattan, 2009.

KLEMENSIEWICZ, Z. Historia języka polskiego. t. 2. Warszawa: PWN, 1985.

KRĄŻYŃSKA, Z.; MIKA, T.; SŁOBODA, A. Składnia średniowiecznej polszczyzny. Czesść I. Konteksty - metody - tendencje. Poznań: Wydawnictwo Rys, 2015.

KUKULSKI, L. Przedmowa. Wprowadzenie. Wstęp. In: KUKULSKI, L. (org.), Maria Kazmiera d'Arquien de la Grange, Listy do Jana Sobieskiego. Tradução de: SELL, J. K.; KUKULSKI, L. Warszawa: Czytelnik, 1966a. p. 5-32.

KUKULSKI, L. (org.) Listy: Maria Kazmiera d'Arquien de la Grange, Listy do Jana Sobieskiego. Tradução de SELL, J. K.; KUKULSKI, L. Warszawa: Czytelnik, 1966b.

KUŹMICKI, M. Współistnienie języków w rotach przysiąg sądowych. In: Slavia Occidentalis, t. 70, p. 75-85, 2013. 
LE BRIZ, S ; VEYSSEYRE, G. (Orgs.) Approches du bilinguisme latin-français au Moyen Âge: linguistique, codicologie, esthétique. Collection d'études médiévales de Nice, 11. Turnhout: Brepols Publishers, 2010.

LIGARA, B. Galicyzmy leksykalne w listach Zygmunta Krasińskiego na tle wpływów francuskich $w$ polszczyźnie XIX wieku (studium bilingwizmu polsko-francuskiego). Kraków: Zeszyty Naukowe UJ, Nakładem UJ, 1987.

LIGARA, B. Bilingwizm polsko-francuski Adama Mickiewicza. W stronę antropologii lingwistycznej. LingVaria, Kraków, n. 2(10), p. 141-170, 2010.

LIGARA, B. Dwujęzyczność twórców literatury polskiej jako problem badawczy historii języka. LingVaria, Kraków, VI, 1 (11), p. 165-178, 2011.

LIGARA, B. Bilingwizm w tekście zapisany. Część I. Status lingwistyczny. Paradygmaty badawcze. LingVaria, Kraków, IX I 1 (17), p. 149-167, 2014a.

LIGARA, B. Bilingwizm w tekście zapisany. Część II. Wykładniki transkodowe. Gatunki. LingVaria, Kraków, IX I 2 (18), p. 139-174, 2014 b.

LIGARA, B. Une vie dans deux langues, le bilinguisme polonais-français de Zygmunt Krasiński à la lumière de son cuvre épistolaire et littéraire, Revue des Études Slaves, tome 86, fascicule 4 "Relations franco-slaves", Paris, p. 427-445, 2015.

LIGARA, B. Badania bilingwizmu (i wielojęzyczności) wybitnych nosicieli języka w przestrzeni języka polskiego: nowa subdomena historii języka? In: PASTUCH, M.; SIUCIAK, M.; WĄSIŃSKIEJ, K.; WILCZEK, W. (Orgs.) Historia języka w XXI wieku. Stan i perspektywy. Katowice: Wydawnictwo Uniwersytetu Śląskiego, 2018. p. 97-108.

LIPIŃSKA, E. Język ojczysty, język obcy, język drugi. Wstęp do badań dwujęzyczności. Kraków: Wydawnictwo UJ, 2003.

MASŁEJ, D. O potrzebie zastosowania terminu wernakularyzacja w polskich badaniach historycznojęzykowych. LingVaria, Kraków, 1, (25), p. 113-122, 2018.

MIODUNKA, W. T. Bilingwizm polsko-portugalski w Brazylii. W strone lingwistyki humanistycznej. Kraków: Universitas, 2003.

MOSS, A. Being in Two Minds: The Bilingual Factor in Renaissance Writing. In: MOSS, A. (orgs.) Acta Conventus Neo-Latini Hafniensis, Binghamton, NY: Medieval \& Renaissance Texts \& Studies, 1994. p. 61-74. 
POLAŃSKI, K. (Orgs.) EJO: Encyklopedia językoznawstwa ogólnego. WrocławWarszawa-Kraków: Zakład Narodowy im. Ossolińskich, 1993.

RZEPKA, W. R.; WALCZAK, B. Socjolekt szlachecki XVII wieku (próba ogólnej charakterystyki). In: STĘPIEŃ, M.; URBAŃCZYK, S. Barok $w$ kulturze, literaturze $i$ języku. Warszawa-Kraków: PWN, 1992. p. 179-188.

STĄPOR, I. Grafia dawnych czasopism Polonii brazylijskiej (na przykładzie Gazety Polskiej w Brazylii). Poradnik Językowy, Warszawa, 2, p. 67-78, 2016.

SZCZEPANKOWSKA, I. Studia nad polszczyzna epoki stanisławowskiej. Białystok: Wydawnictwo Uniwersytetu w Białymstoku, 2004.

TASZYCKI, W. Wybór tekstów staropolskich XVI-XVIII wieku. Warszawa: Państwowe Wydawnictwo Naukowe, 1969.

URBAŃCZYK, S. Polszczyzna Marysieńki Sobieskiej. Język Polski, XLVII, p. 168-173, 1967.

VIDOS, B. E. Le bilinguisme et le mécanisme de l'emprunt. Revue de linguistique romane, 24, p. 1-19, 1960. Disponível em: <https:/www.e-periodica.ch/digbib/ view?pid=rlr-001:1960:24\#10>. Acesso em 06.06.2020.

WALCZAK, B. Trzy refleksje o dwujęzyczności. Poznańskie Spotkania Językoznawcze, Poznań, n. 27, p. 181-191, 2014.

WYDRA, W.; RZEPKA, W. R. Chrestomatia staropolska. Teksty do roku 1543. Wrocław: Zakład Narodowy im. Ossolińskich, 1995.

ZARĘBSKI, R. Bilingwizm polsko-francuski w perspektywie diachronicznej - stan badań i postulaty badawcze. Poradnik Językowy, Warszawa, z. 4, p. 7-20, 2019.

ZIÓŁKOWSKA, O. Specyfika języka Rozmyślań dominikańskich $w$ świetle składni $i$ języka. Poznań: Wydawnictwo Rys, 2016. 